\title{
Low-level heat-treatment to extend shelf-life of fresh fish
}

\author{
PAULO VAZ-PIRES*, CHRISTOPHER CAPELL \& \\ ROY KIRBY \\ Escola Superior de Biotecnologia, Universidade Católica Portuguesa, Porto, Portugal
}

\section{Summary}

The application of heat to reduce the microbial load and extend the lag phase was studied on whole fish and with bacterial isolates from fresh fish in mixed culture. Bacterial isolates obtained from fresh horse-mackerel (Trachurus trachurus) were heat treated at $60^{\circ} \mathrm{C}$ for $20 \mathrm{~s}$ and stored in nutrient broth on ice. The flora were shown to be heat sensitive and the initial numbers were reduced by over $2.0 \log _{10}$ cycles. Heating at $60^{\circ} \mathrm{C}$ extended the lag phase but subsequent growth rates were increased, giving a shelf-life extension of a day and a half. There were no significant effects on visual EC grades of whole fish or on the flavour of cooked fillets.

\section{Keywords}

Horse mackerel, scad, spoilage, Trachurus trachurus.

\section{Introduction}

Surface microbial contamination is one of the principal causes of the spoilage of meat and fish. All animals used to supply meat are homeothermic and their natural microflora is not predominantly psychrotrophic. Psychrophilic contamination comes mainly from environmental sources post-slaughter (Tompkin, 1973). A number of methods which result in a reduction of the psychrophilic contamination have been proposed, including a naked flame, hot air-steam (Smith \& Graham, 1978), dilute acetic acid (Eustace et al., 1979) and decontamination by immersion or spraying (Kelly et al., 1982; Everton, 1985; Crouse et al., 1988). Graham et al. (1978) used $80^{\circ} \mathrm{C}$ water spray washes for $10 \mathrm{~s}$ and reduced the surface bacterial load of lamb carcasses by $2.5 \log$ units.

The microflora of fish is influenced by water temperature (Liston, 1982); fish caught in cold European waters have a large psychrophilic component. Since psychrophilic bacteria are intrinsically associated with the fish this means that refrigeration is less efficient at shelf-life extension. A reduction of the microbial load resulting in an extension of shelf-life of fish and fish products has been achieved with chemical and physical methods including heat treatments: a subject addressed in a recent review by Reddy et al. (1992).

Since psychrophilic bacteria are generally heat sensitive (Olsen \& Nottingham, 1980), mild heat treatments may have a beneficial effect upon the keeping qualities

Authors' address: * Escola Superior de Biotecnologia, R. Dr. António Bernardino de Almeida, 4200 Porto, Portugal.

* Correspondent. Fax: +3512590351. 
of fish. Moderate thermal processing is used to extend the refrigerated shelf-life of some prepackaged seafoods by reducing initial numbers and increasing the time before the onset of exponential growth. The relatively mild heating conditions result in colour, texture, and flavour characteristics similar to 'fresh' products (Hackney, 1990). Provided undesirable changes to the sensory quality can be avoided, mild heat treatments to fresh fish would be an acceptable method of shelf-life extension. This study tests the applicability and effectiveness of such a treatment.

\section{Materials and methods}

\section{Raw materials and sample preparation}

Horse-mackerel (Trachurus trachurus) were caught by bottom trawling, immediately transferred to storage in freshwater ice and stored in the ship's bulk room for 1 or 2 days. After landing, a sample of fish was taken from a single catch and transported to the laboratory in a clean insulated container. The fish were weighed and kept in a refrigerated room $\left(4^{\circ} \mathrm{C} \pm 1^{\circ} \mathrm{C}\right)$ packed in ice in boxes.

The average weight of each fish was $215 \mathrm{~g}$ (minimum $191 \mathrm{~g} /$ maximum $285 \mathrm{~g}$; male to female ratio approximately $1: 1$ ).

\section{Microbiological analysis}

Media and reagents. Serial dilutions were made in sterile 1/4 strength Ringers solution (Lab M). Nutrient agar and nutrient broth (Lab M) were used as solid and liquid growth media. Media and reagents were prepared according to manufacturers' instructions.

Isolation and testing of bacteria. Pieces of skin (about $2 \mathrm{~cm}^{2}$ ), gill (one whole gill arch) and abdominal cavity (all organs) aseptically taken from freshly caught fish (2 days after catch) were separately homogenized in $20 \mathrm{ml}$ of Ringers solution for $2 \mathrm{~min}$ and bacteria were isolated on nutrient agar spread plates incubated at $10^{\circ} \mathrm{C}$. For 80 initial purified isolates, gram reaction, cell shape and colony morphology were noted. Isolates were noted and 30 were chosen for their diversity of reactions and appearance to represent as large as possible a range of heat resistances. They were separately grown in nutrient broth for $48 \mathrm{~h}$ at $30^{\circ} \mathrm{C}$. For replicate experiments cocktails were always produced using identical conditions. These cultures were then mixed in equal volume to form a cocktail and $0.5 \mathrm{ml}$ of the mixture was added to $49.5 \mathrm{ml}$ of stirred Ringers solution at $60^{\circ} \mathrm{C}$. After $20 \mathrm{~s}, 0.5 \mathrm{ml}$ were taken from the Ringers solutions and put into $49.5 \mathrm{ml}$ of nutrient broth pre-stored on ice. A control was simultaneously performed using Ringers at $30^{\circ} \mathrm{C}$. Counts were made on nutrient agar plates (incubated at $30^{\circ} \mathrm{C}$ for $48 \mathrm{~h}$ ) over the following 3 weeks.

Total counts on fish. A sample of 12, 2-day post-mortem fish was equally divided and treated by total immersion in heated tap water for $20 \mathrm{~s}$, six at $30^{\circ} \mathrm{C}$ (control) and six at $60^{\circ} \mathrm{C}$. Afterwards the fish were immediately replaced into ice which was replenished regularly and from which drip water was removed. Fish boxes were stored at $4 \pm 1^{\circ} \mathrm{C}$ in a refrigerated room. At regular intervals a fish from each sample was selected randomly and circle punch samples of skin were taken aseptically from the region behind the operculum above the pectoral fin and homogenized in sterile 
Ringers solution. Counts were made on nutrient agar plates $\left(22^{\circ} \mathrm{C}\right.$ for $\left.48 \mathrm{~h}\right)$ as previously described.

\section{Grading and scoring of appearance of raw fish}

Untreated. Three trained panellists graded three fish of each group every 2 days, according to the European Community (E.C.) fish sensory scheme (Howgate et al., 1992). Each of the panellists was asked to perform an evaluation of the appearance of the skin, slime, eyes, gills and internal organs, the texture and smell. Fish were classified by attributing three points to ' $E$ ' or 'Extra', two points to 'A', one point to ' $B$ ' and no points to 'C' or 'Unfit' for each of the above characteristics, as described by Huss (1988). The final grade of each fish was calculated from the mean of all points attributed and the final grade for each day was calculated from the mean of the fish examined.

Treated. Twenty raw fish were randomly assigned time/temperature combination treatments (in the range of $55-80^{\circ} \mathrm{C}$ and $10-60 \mathrm{~s}$ ), then processed by total immersion in heated tap water in a $20-\mathrm{L}$ water bath. The fish were distributed on a white surface in a $4 \times 5$ matrix, with one identified control as a visual reference. One unidentified control was also included. Forty-seven panellists, including professional buyers of fish, were asked to classify the fish with reference to the control, looking only at external aspects, and using the words 'same', 'similar' or 'different'. Comments about the differences were also asked for.

\section{Cooked fish}

Twelve fish were divided equally into two groups. Both samples were processed for $20 \mathrm{~s}$ by total immersion in heated tap water, one at $30^{\circ} \mathrm{C}$ and the other at $60^{\circ} \mathrm{C}$. From each fish eight fillets were cut and cooked for $10 \mathrm{~min}$ in a steam cooker over a metallic grid. A triangular test to determine organoleptic distinctiveness was conducted by 18 panellists. The $\chi^{2}$ test was performed according to Box et al. (1978).

\section{Results}

All results are the mean of at least duplicate experiments.

\section{Heat resistance of bacterial isolates}

All 80 isolates were found to be gram negative, catalase positive and oxidase positive. When subjected to heat stress using a variety of time temperature combinations, cocktails of bacterial isolates from fresh sea fish consistently demonstrated a sensitivity to heat (Fig. 1). A treatment of $60^{\circ} \mathrm{C}$ for $20 \mathrm{~s}$ resulted in a reduction of two $\log$ cycles. Data collected (not shown) gave a collective $D_{60}$ for the cocktail of $10 \mathrm{~s}$. Heating at $60^{\circ} \mathrm{C}$ for $20 \mathrm{~s}$ also resulted in an increase in the lag phase of survivors of 4-5 days when compared with the control.

\section{Effect of heat treatment on whole fish surface flora}

Dipping fish in water held at $60^{\circ} \mathrm{C}$ did not reduce the total viable count (TVC) of samples of skin taken immediately after treatment, as compared with the controls. These results are in agreement with similar experiments performed on meat carcasses (Powell \& Cain, 1987). Growth curves derived from skin samples on treated and 


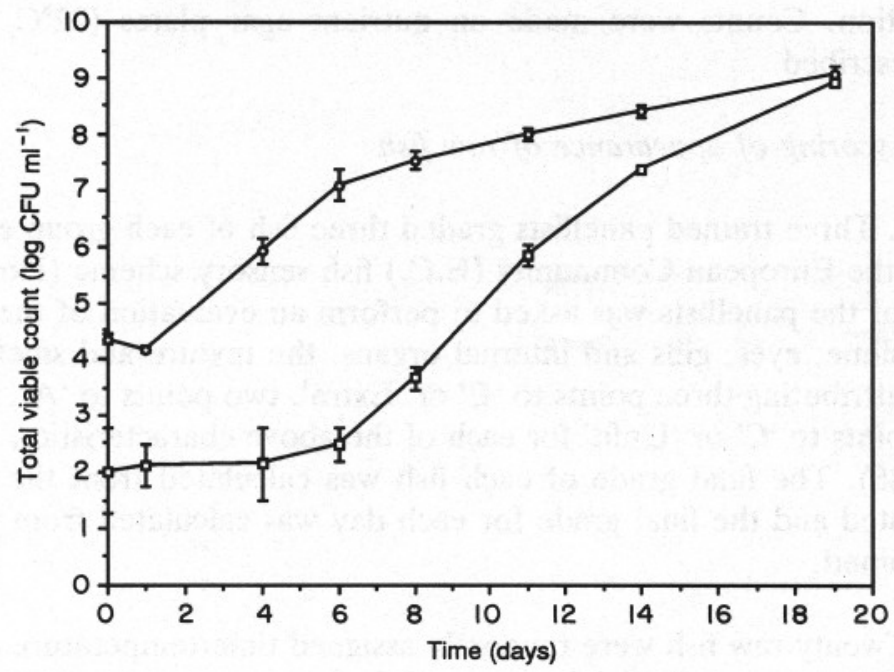

Figure 1. Effect of heat stress on mixed cultures of bacteria isolated from horse mackerel (Trachurus trachurus $)$ and on subsequent growth of the bacteria in nutrient broth on ice. $\circ, 30^{\circ} \mathrm{C}$ and $\square, 60^{\circ} \mathrm{C}\left( \pm 2 \sigma_{n-1}\right)$.

untreated fish (Fig. 2) are similar to those in broth (Fig. 1). Results show that the onset of growth was delayed for approximately 4 days following heat treatment. The subsequent growth rate of bacteria on the treated fish was greater than that observed with the control and the two counts converged after a further 4 days. The qualitative effect of the treatment on the microflora of the fish was not determined.

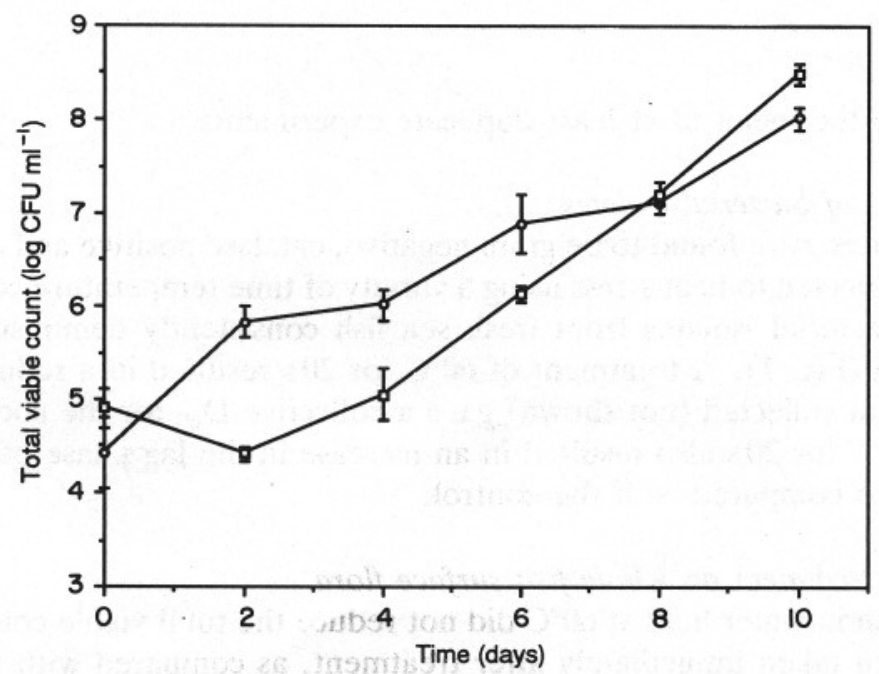

Figure 3. Graph showing total viable counts per $\mathrm{cm}^{2}$ of fish skin during 10 days of storage in ice. $\circ, 30^{\circ} \mathrm{C}$ and $\square, 60^{\circ} \mathrm{C}\left( \pm 2 \sigma_{n-1}\right)$. 
(1) Visual. Results in Fig. 3 show that fish treated at temperatures of between 55 and $70^{\circ} \mathrm{C}$ for times of between 10 and $30 \mathrm{~s}$ were indistinguishable from untreated fish. A score of less than 10 indicates that less than three panellists scored the fish as different. Fish were analysed by a panel of 47 people composed of professional and non-professional buyers.

(2) Organoleptic. The triangular test on cooked samples of heat treated and control fish resulted in a value of $\chi_{(\text {d.f. }=1)}^{2}=4.0(P<0.01)$. The expected results were six correct and 12 incorrect, and the observed two correct and 16 incorrect. A treatment of $60^{\circ} \mathrm{C}$ for $20 \mathrm{~s}$ resulted in no detectable difference in the fish. Statistical analysis of the results in relation to the heat treatment show that the null hypothesis is not rejected at a level of significance of $1 \%$.

\section{Spoilage following treatment}

Spoilage of treated and untreated fish was followed by organoleptic and microbiological analysis. The results are shown in Figs 2 and 4 respectively. The organoleptic analysis used quality bands E (extra quality), A (good), B (acceptable) and C (unfit), therefore when the fish leaves band $\mathrm{B}$ it is no longer acceptable for consumption as human food. Lines were drawn in the graph, showing the limits of each category (Extra $\geq 2.7$ points; $\mathrm{A} \geq 2.0 ; \mathrm{B} \geq 1.0$ and Unfit or $\mathrm{C}<1.0$ ). Linear regression analysis shows that organoleptic rejection of the fish was reached after 10.5 days in the case of treated fish and 9 days in the case of untreated fish. An increase of 1.5 days

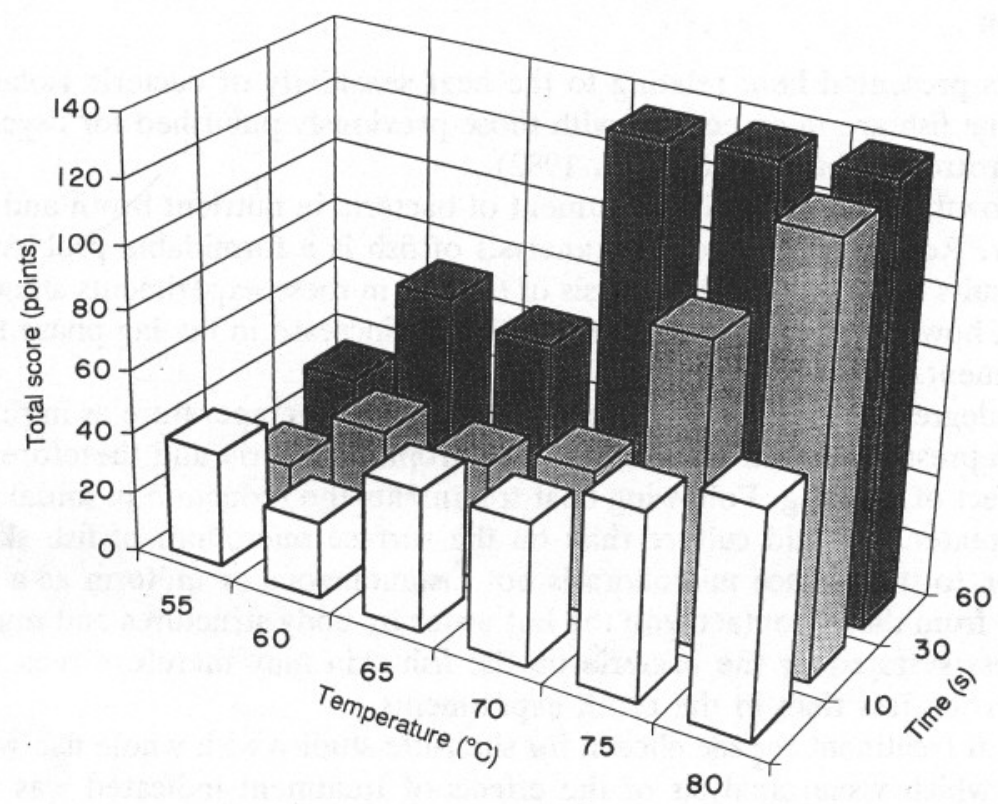

Figure 3. The effect of temperature/time combinations of heat treatments on the external visual characteristics of horse mackerel (Trachurus trachurus) by a panel of 47 people. The scoring system was: 0 points, same as control; 1 point, similar to control; and 3 points, different from control. 


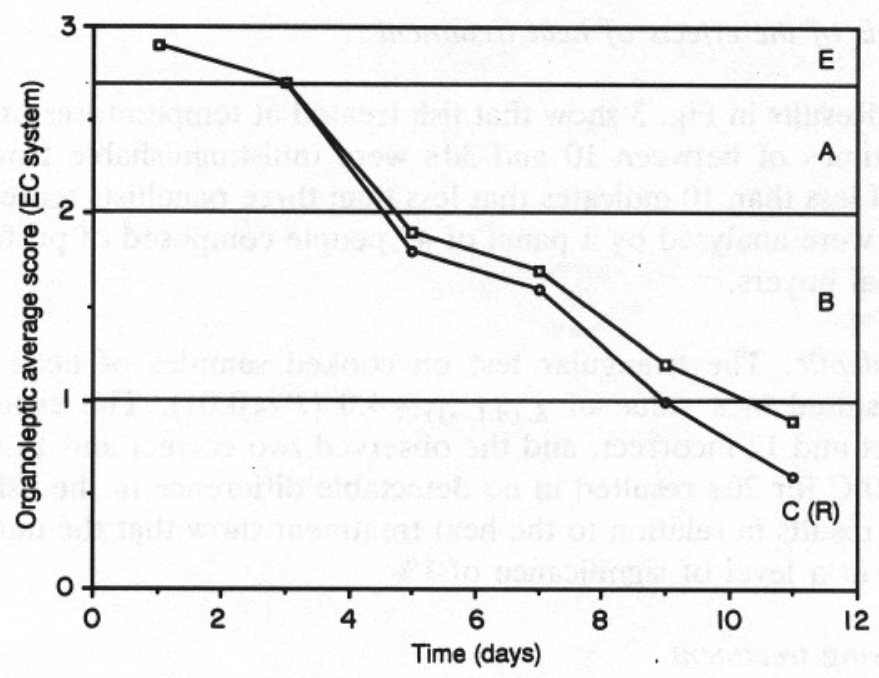

Figure 4. The progression of organoleptic panel scores of horse mackerel (Trachurus trachurus) over time stored in ice after heat treatment. $0,30^{\circ} \mathrm{C}$ and $\square, 60^{\circ} \mathrm{C}$. E (extra) and $\mathrm{A}, \mathrm{B}, \mathrm{C}$ (unfit) are grading standards of the European community.

in the time to rejection was achieved. The organoleptic analysis in the early stages of spoilage show no divergence in bands $\mathrm{E}$ and $\mathrm{A}$; in band $\mathrm{B}$ however, the organoleptic assessment of the treated fish consistently received slightly higher quality

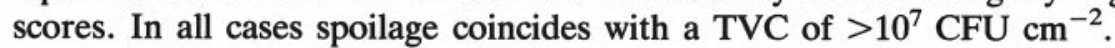

\section{Discussion}

The results presented here relating to the heat sensitivity of bacteria isolated from fresh marine fish are in agreement with those previously published for psychrophilic and psychrotrophic bacteria (Liston, 1982).

The growth curves following treatment of bacteria in nutrient broth and fish skin are similar. Reproducible microbial analysis of fish is a formidable problem (Huss, 1988). Results of the microbial analysis of the fish in these experiments showed large variations, however, both growth curves show an increase in the lag phase following heat treatment.

Thirty degrees centigrade was chosen as the control temperature as in principle it does not represent a lethal stress for psychrotrophic bacteria and therefore controls for the effect of washing. Following heat treatments the reduction in initial numbers is much greater in liquid culture than on the surface microflora of fish skin. Heat penetration to the surface microflora is not instantaneous or uniform as a result of protection from direct contact with the hot water by body structures and mucus. The actual stress suffered by the bacteria on the fish skin may therefore reasonably be expected to be less than in the broth experiments.

The heat treatment regime chosen for shelf-life studies with whole fish was not at the limits which visual analysis of the effects of treatment indicated was possible. Sprays have previously been reported as being difficult to use (Smith \& Graham, 1978; Everton, 1985) with immersion being more effective in controlling the time and temperature of exposure. In experiments with meat carcasses, Powell \& Cain 
(1987) reported that temperature differences between the surface and spray water ranged from 1 to $7^{\circ} \mathrm{C}$ depending upon the contact time: temperature differences along the surface of the carcass were, however, less than $1^{\circ} \mathrm{C}$. As a result of practical difficulties in controlling conditions in industrial situations, a treatment regimen was chosen which would give a reasonable safety margin allowing for over processing.

The larger than expected number of incorrect results in the triangular test could mean very small differences between samples or very large within-sample variation. The panellists were however, unable to detect the differences induced by heat treatment. This could be expected, as the treatment of $20 \mathrm{~s}$ at $60^{\circ} \mathrm{C}$ may be considered almost negligible when compared to the cooking procedure of $10 \mathrm{~min}$ at approximately $100^{\circ} \mathrm{C}$. Poor understanding by the panel of the test as an explanation of the results is not probable, as clear verbal and written instructions were given to all panellists.

Spoilage after treatment was followed organoleptically and microbiologically: the results for the two types of analysis do not agree. In the early stages following treatment there is no bacterial growth, however no benefit in quality is demonstrated in the organoleptic quality analysis. This would seem to indicate that initial losses in quality are not related to bacterial activity but to enzymic autolysis. These findings are in agreement with the findings of Huss (1988).

It has previously been reported (Hobbs, 1991) that extending the lag phase of bacteria will extend shelf-life. The results presented here demonstrate that even with an extended lag phase there remains the possibility of more rapid subsequent growth, which may reduce or eliminate the advantage gained from the delayed onset of growth. More rapid growth following treatment may occur because some of the competitive microflora is removed.

Post-process contamination with psychrophilic bacteria may offer an alternative explanation for the limited success of the treatment. Vogel \& Silliker (1972) indicated that refrigerated workrooms in the meat and poultry trade may be considered as counter productive with regard to shelf-life extension for this reason. During the course of the experiments all possible care was taken to avoid this problem; in industrial applications, however, it may be more relevant.

Gutted fish have previously been reported by many authors to have an extended shelf-life in comparison with ungutted fish (Scott $e$ t al., 1986). The reduction of the gut microflora which can be expected to occur as a result of the removal of internal organs may in part account for this. The results presented here are taken only from experiments with ungutted fish. Experiments with gutted fish may be expected to be more successful as the gutting process would make the internal cavities an external surface reachable by the hot water, thereby delaying bacterial growth. The problem of the kinetics of subsequent growth encountered in these experiments would, however, remain. According to Pedrosa-Menabrito \& Regenstein (1988) a poor gutting job can sometimes be more harmful than not gutting at all because of the introduction of contamination. In this particular case, hot water treatments may improve product quality.

In general the results demonstrate the difficulties that have previously been encountered with other attempts to extend the shelf-life of food products (Rippen \& Hackney, 1992; Ellerbroek et al., 1993); that is low-level treatments aimed at reducing the initial microflora may not be successful. The result of these treatments may be to alter the organisms spoiling the product and not delay rejection. It has been previously published that hot water improves meat washing processes, as well as acidification of the water (Ellerbroek et al., 1993). Shelf-life of meat is improved 
with acids (Everton, 1985). Future work must therefore concentrate on the use of combinations of barriers to growth to effectively delay the spoilage of fresh food products.

\section{Acknowledgments}

This work was supported by JNICT (Junta Nacional de Investigação Científica e Tecnológica, Portugal). We wish to thank José Carlos Soares for donations of samples, Vítor Sousa Pereira for technical information and support and Luciano Ferreira for his excellent technical assistance.

\section{References}

Box, E.P., Hunter, W.G. \& Hunter, J.S. (1978). In: Statistics for Experimenters - an Introduction to Design, Data Analysis, and Model Building, pp. 118-122. New York: John Wiley \& Sons.

Crouse, J.D., Anderson, M.E. \& Naumann, H.D. (1988). Microbial decontamination and weight of carcass beef as affected by an automated washing pressure and length of time of spray. Journal of Food Protection, 51, 471-474.

Ellerbroek, L.I., Wegener, J.F. \& Arndt, G. (1993). Does spray washing of lamb carcasses alter bacterial surface contamination? Journal of Food Protection, 56, 432-436.

Eustace, I.J., Powell, V.H. \& Bill, B.A. (1979). Vacuum packaging of lamb carcasses: use of acetic acid to extend chill storage life. A preliminary investigation, Meat Research Report 3/79. Australia: Division of Food Research, Meat Research Laboratory.

Everton, A.R. (1985). Attempts to reduce the microbiological contamination of raw meat. The Meat Hygienist, Sept. 1985, 3-10.

Graham, A., Eustace, I.J. \& Powell, V.H. (1978). Surface decontamination - a new processing unit for improved hygiene on carcass meat. Proceedings of the 24th European Meeting of Meat Research Workers. Kulmbach, pp. B8:1-B8:6.

Hackney, C.R. (1990). Processing molluscs. In: Seafood Industry (edited by R.E. Martin and G.J. Flick). pp. 165-173. New York: Van-NostrandReinhold.

Hobbs, G. (1991). Fish: microbiological spoilage and safety. Food Science and Technology Today, 5, 166-173.

Howgate, P., Johnston, A. \& Whittle, K.J. (1992). Multilingual Guide to EC Freshness Grades for Fishery Products. Aberdeen: Torry Research Station, Food Safety Directorate, Ministry of Agriculture, Fisheries and Food.

Huss, H.H. (1988). In: Le Poisson Frais: Qualité et Alterations de La Qualité, pp. 29-102. Organization des Nations Unites pour l'Alimentation et l'Agriculture. Collection FAO: Pêches, $\mathbf{n}^{\circ} 29$.

Kelly, C.C., Lynch, B. \& McLoughlin, A.J. (1982). The effect of spray washing on the development of bacterial numbers and storage life of lamb carcasses. Journal of Applied Bacteriology, 53, $335-341$.

Liston, J. (1982). Recent advances in the chemistry of iced fish spoilage. In: Chemistry and Biochemistry of Marine Food Products (edited by R.E. Martin, G.J. Flick, C.E. Hebard \& D.R. Ward). pp. 27-36. Westport, CT: AVI Publishing Co.

Olsen, J.C. \& Nottingham, P.M. (1980). Temperature. In: Microbial Ecology of Foods, vol. I - Factors affecting life and death of microorganisms, pp. 1-37. International Commission on Microbiological Specifications for Foods, London: Academic Press.

Pedrosa-Menabrito, A. \& Regenstein, J.M. (1988). Shelf-life extension of fresh fish - a review. Part I - Spoilage of fish. Journal of Food Quality, 11, 117-127.

Powell, V.H. \& Cain, B.P. (1987). A hot water decontamination system for beef sides, CSIRO Food Research Quarterly, 47, 79-84. Queensland, Australia: Commonwealth Scientific and Industrial Research Organization.

Reddy, N.R., Armstrong, D.J., Rhodehamel, E.J. \& Kautter, D.A. (1992). Shelf-life extension and safety concerns about fresh fishery products packaged under modified atmospheres: a review. Journal of Food Safety, 12, 87-118.

Rippen, T.E. \& Hackney, C.R. (1992). Pasteurization of Seafood: Potential for shelf-life extension and pathogen control. Food Technology, 46, 88-94.

Scott, D.N., Fletcher, G.C., Hogg, M.G. \& Ryder, J.M. (1986). Comparison of whole with headed and gutted orange roughy stored in ice: sensory, microbiology and chemical assessment. Journal of Food Science, 51, 79-83.

Smith, M.G. \& Graham, A. (1978). Destruction of Escherichia coli and salmonellae on mutton carcases by treatment with hot water. Meat 
Science, 2, 119-128.

Tompkin, R.B. (1973). Refrigeration temperature as an environmental factor influencing the microbial quality of food - a review. Food
Technology, 27, 54-58.

Vogel, P.W. \& Silliker, J.H. (1972). Meat Processing. U.S. Patent No. 3705813. 